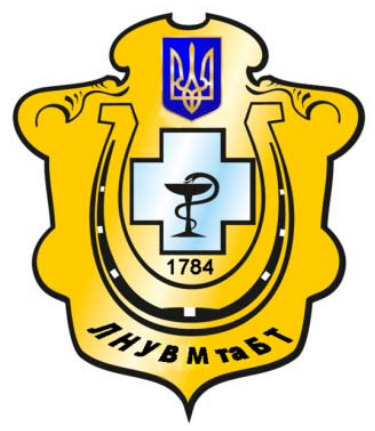

Науковий вісник Львівського національного університету ветеринарної медицини та біотехнологій імені С.3. Гжицького

Scientific Messenger of Lviv National University of Veterinary Medicine and Biotechnologies named after S.Z. Gzhytskyj

doi:10.15421/nvlvet7506

ISSN 2519-268X print

ISSN 2518-1327 online

$\underline{\text { http://nvlvet.com.ua/ }}$

УДК 579.22

\title{
Дослідження впливу складу захисного середовища на збереження життсздатності ліофілізованих бактерій L. lactis та L. plantarum, виділених із традиційної карпатської бринзи
}

\author{
О.Й. Цісарик, І.М. Сливка, Л.Я. Мусій \\ tsisaryk_o@yaoo.com, slyvka.88@ukr.net,musiyluba@ukr.net
}

\begin{abstract}
Львівський начіональний університет ветеринарної медицини та біотехнологій імені С.З. Гюсицького, вул. Пекарська, 50, м. Львів, 79010, Украӥна
\end{abstract}

\begin{abstract}
Вивчено вплив складу захисних середовищ на збереження життєздатності та технологічні властивості ліофілізованих бактерій штамів L. lactis ma L. plantarum. Для досліджень обрано білково-вуглеводне та сахарозо-желатозне середовища. Об'єктами досліджень були чисті культури молочнокислих бактерій (МКБ): L. lactis SB 16, L. lactis SB 44, L. plantarum SB 5, L. plantarum SB 7, L. plantarum SB 17, виділені на попередніх етапах роботи із традиційної бринзи, виготовленої у непромислових умовах Карпатського регіону Украӥни. Культури бактерій ідентифіковано із використанням класичних мікробіологічних і сучасних молекулярно-генетичних методів (RAPD-PCR, RFLP-PCR, секвенування гену $16 S$ pPHK). Чисельність мезо- і термофільних лактобактерій визначали иляхом посіву на середовище MRS. Молокозсідальну активність монокультур визначали за зміною кислотності молока. Прочес сублімачійного сушіння біомаси, змішаної із відповідною кількістю захисного середовища, здійснювали із використанням сублімаиійної сушарки «Alpha 1,2 LD Plus». За визначеною експериментальним шляхом кількістю загиблих під час сушіння клітин встановлювали Рівень Збереження Життєздатності (РЗЖ) різних видів і штамів. Встановлено, шо за своїми кріопротекторними властивостями крашим для сушіння клітин досліджених монокультур є сахарозо-желатозне середовище, яке забезпечує високий РЗЖ, особливо для L. lactis SB 16 (кількість загиблих під час сушіння клітин становила 9,2\%) та L. plantarum SB 17 (кількість загиблих під час сушіння клітин становила 9,9\%). Проведено порівняльне дослідження РЗЖ різних видів МКБ за різних умов зберігання. Встановлено, щьо усі штами молочнокислих бактерій, за винятком штаму L. lactis SB 16, протягом зберігання у знежиреному молоиі за температури (+6) ${ }^{\circ}$ С через місяць втрачають від 4 до 15\% життездатних клітин. Термін зберігання штамів L. lactis ma L. plantarum y сухій культурі становить 6 міс.

Ключові слова: бринза, мезофільні лактококи, термофільні стрептококи, чисельність клітин, захисні середовища, сахарозо-желатозне середовище, білково-вуглеводне середовище, рівень збереження життєздатності, ліофілізовані культури.

\section{Исследование влияния состава защитной среды на сохранения жизнеспособности лиофилизированных бактерий L. lactis и L. plantarum, выделенных из традиционной карпатской брынзы}

\author{
О.Й. Цисарык, И.Н. Сливка, Л.Я. Мусий \\ tsisaryk_o@yaoo.com, slyvka.88@ukr.net, musiyluba@ukr.net
}

Львовский национальный университет ветеринарной медицины и биотехнологий имени С.3. Гжицкого, ул. Пекарская, 50, г. Львов, 79010, Украина

Изучено влияние состава защитных сред на сохранение жизнеспособности и технологические свойства лиофилизированных бактерий штаммов L. lactis и L. plantarum. Для исследований избраны белково-углеводная и сахарозо-желатозная среды. Объектали исследований были чистые культуры молочнокислых бактерий (МКБ): L. lactis SB 16 L. lactis SB 44, L.

\section{Citation:}

Tsisaryk, O.I., Slyvka, I.M., Musiy, L.Ia. (2017). The research of the influence of the content of protective environment for the preservation of viability of lyophilized bacteria L. lactis and L. plantarum, from traditional Carpathian bryndza. Scientific Messenger LNUVMBT named after S.Z. Gzhytskyj, $19(75), 29-34$. 
plantarum SB 5, L. plantarum SB 7, L. plantarum SB 17, выделенные на предыдущих этапах работы из традиционной брынзы, изготовленной в кустарных условиях Карпатского региона Украины. Культуры бактерий идентифицированы с использованием классических микробиологических и современных молекулярно-генетических методов (RAPD-PCR, RFLP-PCR, cеквенирование гена $16 S$ рPHК). Численность мезо- и термофильных лактобактерий определяли путем посева на среду MRS. Молокосвертывающую активность монокультур определяли по изменению кислотности молока. Процесс сублимационной сушки биомассы, смешанной с соответствующим количеством защитной среды, осуществляли с использованием сублимаиионной сушки «Alpha 1,2 LD Plus». По определенной экспериментальным путем количества погибших во время сушки клеток устанавливали Уровень Сохранения Жизнеспособности (УСЖ) различных видов и штаммов. Установлено, что по своим криопротекторными свойствами лучшим для сушки исследованных монокультур является сахарозо-желатозная среда, обеспечивающая высокий РЗЖ, особенно для L. lactis SB 16 (количество погибших за сушки клеток составляло 9,2\%) u L. plantarum SB 17 (количество погибших за сушки клеток составляло 9,9\%). Проведено сравнительное исследование УСЖ различных видов МКБ при различных условиях хранения. Установлено, что все штаммы молочнокисльх бактерий, за исключением штамма L. lactis SB 16 при хранении в обезжиренном молоке при температуре (+6) ${ }^{\circ} \mathrm{C}$ через месяи теряют от 4 до 15\% жизнеспособных клеток. Срок хранения штаммов L. lactis и L. plantarum в сухой культуре составляет 6 мес.

Ключевые слова: брынза, мезофильные лактококки, термофильные стрептококки, численность клеток, защитные среды, сахарозо-желатозная среда, белково-углеводная среда, уровень сохранения жизнеспособности, лиофилизированные культуры.

\title{
The research of the influence of the content of protective environment for the preservation of viability of lyophilized bacteria $L$. lactis and $L$. plantarum, from traditional Carpathian bryndza
}

\author{
O.I. Tsisaryk, I.M. Slyvka, L.Ia. Musiy \\ tsisaryk_o@yaoo.com, slyvka.88@ukr.net,musiyluba@ukr.net \\ Lviv National University of Veterinary Medicine and Biotechnologies named after S.Z. Gzhytskyi, \\ Pekarska Str. 50, Lviv, 79010, Ukraine
}

\begin{abstract}
The influence of the content of protective environment for the preservation of viability and technological properties of lyophilized bacteria of stains L. lactis ma L. plantarum is studied in the article. Protein and carbohydrate and sucrose-gelatin environment were selected for the research. The objects of the research were pure cultures of lactic acid bacteria: L. lactis SB 16, L. lactis SB 44, L. plantarum SB 5, L. plantarum SB 7, L. plantarum SB 17, extracted on the previous stages of work from traditional bryndza, produced in non-industrial conditions of Carpathian region of Ukraine. Cultures of bacteria were identified using classical microbiological and modern molecular-genetic methods (RAPD-PCR, RFLP-PCR, gene sequencing $16 S$ pPHK). The number of mesophilic and thermophilic lactobacilli were determined using the method of sowing on the environment MRS. Cheese producing activity of monocultures was determined by the change in acidity of milk. The process of freeze-drying of biomass, mixed with the appropriate amount of protective environment, was carried out using freeze-dryer "Alpha 1.2 LD Plus». The Level of Viability Preservation (LVP) of different types and strain was set using experimental method of determination of the amount of dead cells during the process of drying. It is determined that according to its cryoprotective peculiarities sucrose-gelatin environment is better for the process of monocultures drying, which secures high LVP, in particular for L. lactis SB 16 (the number of dead cells during drying was 9.2\%) and L. plantarum SB 17 (the number of dead cells during drying was 9.9\%). The comparative research of LVP of different types of lactic acid bacteria at different types of storages. It is determined that all these strains of lactic acid bacteria, with the exception of the strain L. lactis SB 16 during the storage in skimmed milk at a temperature (+6) ${ }^{\circ} \mathrm{C}$ after a month lose from 4 to $15 \%$ of live cells. The term of storage of strains L. lactis and L. Plantarum in dry culture is 6 months.
\end{abstract}

Key words: bryndza, mesophilic Lactococcus, thermophilic streptococci, the number of cells, protecting environment, sucrosegelatin environment, protein and carbohydrate environment, preserve the viability level, lyophilized culture.

\section{Ветуп}

В Україні для виробництва кисломолочних продуктів та сирів здебільшого використовують імпортні бактеріальні препарати, які характеризуються різним складом мікробіальних культур, відповідно різною ефективністю щодо формування споживних та функціональних властивостей. Натомість, немає вітчизняних бактеріальних препаратів, склад яких би відтворював природний склад культур молочнокислих бактерій традиційних ферментованих продуктів (Slyvka and Cisaryk, 2016).

Перспективним нововведенням у промисловій біотехнології та функціональному харчуванні $є$ створення ліофілізованих культур лактобактерій, виділених із природних еконіш для виробництва молочних продуктів (Basjul et al., 2014). Підбір захисного середовища для ліофілізації сприяє підвищенню стійкості бактеріальних клітин до ушкоджень у процесі ліофільного сушіння, стабілізації їх життєвих функцій і збереженню високої кількості життездатних клітин протягом тривалого часу після сушіння (Belov et al., 1993; Golovach and Groma, 2004).

Будь-яка технологія сухих бактеріальних концентратів передбачає ферментування поживного середовища культурами, отримання біомаси клітин та подальше іiі консервування шляхом переведення мікроорганізмів у анабіотичний стан для збереження їх властивостей упродовж усього терміну застосування. Для цього використовують різні фізичні та фізико-хімічні засоби впливу на біомасу, зокрема, проводять іï заморожування та сушіння (Jeres'ko et al., 2001).

При проведенні технологічних операцій, мікроорганізми усіх без винятку видів, піддаються значним 
механічним та температурним впливам. Апробація різних варіантів сушіння біомаси показала, що забезпечення мінімальної кількості загиблих клітин, а отже і збереження високої активності готового бактеріального препарату найкраще вдається за використання сублімаційного сушіння. Індивідуальна чутливість клітин кожного виду і навіть штаму мікроорганізму до заморожування і дефростації залежить від їх можливості зберігати фізіологічні функції за різного вмісту вологи (Golovach and Groma, 2004).

Численні багаторічні дослідження показали, що пом'якшити негативну дію екстремальних температур на живу клітину здатні захисні середовища, створені на основі спеціально підібраних кріозахисних сполук. Їхнє використання на стадії досягнення мікроорганізмом під час культивування стаціонарної фази росту хоча й не дає стовідсоткової гарантії виживання усіх клітин, проте сприяє істотному зменшенню втрат нагромадженої біомаси (Basjul et al., 2014). За відсутності кріозахисних речовин бактеріальні клітини зазнають значних змін, які супроводжуються розкладом клітинних структур і втратою їх життєздатності.

Визначальну роль у кріостійкості бактерій відіграють вік культури, склад живильного середовища, спосіб концентрування, фізико-хімічні властивості компонентів клітинних мембран, склад та структурна організація мембран, стадія розвитку бактерій, швидкість заморожування тощо (Romeo et al., 2001).

Основними факторами, що впливають на збереження бактеріями метаболічної активності після заморожування і сушіння $є$ температура розтоплення біомаси, інтенсивність та характер іiі перемішування, компонентний склад захисного середовища, а також співвідношення між кількістю мікробної маси і концентрацією захисних речовин. Такі фізичні параметри, як швидкість заморожування мікробної суспензії, особливості надходження тепла до поверхні випаровування, швидкість видалення води і швидкість потоку пари обумовлюють ефективність сушіння мікробних клітин (Blankov and Klebanov, 1987).

Метою наших досліджень було вивчити вплив складу захисних середовищ під час сублімаційного сушіння на збереження життєздатності та технологічні властивості різних штамів L. lactis та L. plantarum після ліофілізації та під час зберігання у знежиреному молоці за температури $(+6)^{\circ} \mathrm{C}$, а також у ліофілізованому стані за температури $(-18){ }^{\circ} \mathrm{C}$.

\section{Матеріал і методи досліджень}

У дослідженнях використано культури молочнокислих бактерій, виділені із бринзи, що виготовляється із овечого молока у непромислових умовах Карпатського регіону України.

Культури бактерій ідентифіковано із використанням класичних мікробіологічних і сучасних молекулярно-генетичних методів (RAPD-PCR, RFLP-PCR, секвенування гену 16S pРHК) (Cisary et al., 2014; Cisaryk and Slyvka, 2015). Ці штами за комплексом морфологічних, культуральних, біохімічних показників та генотипових ознак віднесені до виду Lactococcus lactis та Lactobacillus plantarum, однак за нуклео- тидною послідовністю не зареєстровані у Gene Bank. Штамам присвоєно назву L. lactis SB 16, L. lactis SB 44, L. plantarum SB 5, L. plantarum SB 7, L. plantarum SB 17 та проведено їх скринінг.

Чисельність мезо- і термофільних лактобактерій визначали шляхом посіву на середовище MRS. Молокозсідальну активність оцінювали за зниженням pH та наростанням титрованої кислотності молока, сквашеного відповідним бактеріальним штамом (Sbornik... 1985). Вимірювання активної кислотності проводили за допомогою електронного $\mathrm{pH}$-метра «Muttler Toledo MP220». Титровану кислотність молока визначали за ГОСТ 3624-92 «Молоко і молочні продукти. Титрометричні методи визначення кислотності».

У дослідженнях використано захисні середовища iз таким співвідношенням основних речовин:

1) білково-вуглеводне - сухе знежирене молоко (30\%), сахароза (10\%) та цитрат натрію (5\%);

2) сахарозо-желатозне середовище - $13-16 \%$ розчин желатину (80-100 г желатину розчинений у $600 \mathrm{~cm}^{3}$ дистильованої води) змішаний із $250 \mathrm{~cm}^{3}$ розчину 500 г сахарози (50\%) у загальному об'ємі розчину 1 дм $^{3}$, який піддавали стерилізації упродовж 2 годин за тиску 1,5 атм.

Підготовку досліджуваних бактерій до ліофілізації проводили шляхом вирощування їх у рідкому середовищі MRS в умовах періодичного культивування протягом 24 годин 3 наступним концентруванням на центрифузі Thermo Scientific при 1500 об./хв. протягом 15 хв. Суспензію бактерій змішували із захисним середовищем у співвідношенні $1: 2$, розливали порціями по 5 мл у стерильні пеніцилінові флакони, які прикривали стерильними марлевими серветками та ліофілізували за початкової температури $(-15){ }^{\circ} \mathrm{C}$ і кінцевої $(-55){ }^{\circ} \mathrm{C}$. Флакони 3 ліофілізованою культурою закривали стерильними металевими ковпачками, маркували та закладали на зберігання за температури $(+4-6){ }^{\circ} \mathrm{C}$.

Процес сублімаційного сушіння біомаси, змішаної iз відповідною кількістю захисного середовища здійснювали із використанням сублімаційної сушарки фірми «Alpha 1,2 LD Plus».

Обчислення кількості клітин $\left(\mathrm{N}_{2}\right)$, загиблих під час сублімаційного сушіння монокультур, проводили за формулою:

$$
\begin{gathered}
\mathrm{N}_{1}=\lg \mathrm{KУO}_{2} \times 100 / \lg \mathrm{KУO}_{1} \\
\mathrm{~N}_{2}=100-\mathrm{N}_{1}
\end{gathered}
$$

де

$\lg \mathrm{KУО}_{1}$ - кількість клітин у 1 г сирої біомаси після центрифугування;

$\lg \mathrm{KУO}_{2}-$ кількість клітин у тому самому зразку після сушіння.

$\mathrm{N}_{1}$ - кількість життєздатних клітин, що залишилися, $\%$;

$\mathrm{N}_{2}$ - кількість клітин, загиблих під час сублімаційного сушіння монокультур, \%.

\section{Результати та їх обговорення}

Для використання молочнокислих бактерій, як заквашувальних культур для традиційних кисломолочних продуктів та різноманітних напоїв, необхідно 
мати гарантії збереження ними високої фізіологічної активності упродовж тривалого часу.

За визначеною експериментальним шляхом кількістю загиблих під час сушіння клітин встановлюють рівень збереження життєздатності (РЗЖ) різних видів i штамів лактобактерій. Цей показник можна використовувати не тільки, як критерій відбору культур до складу заквашувальних композицій, але й виявити особливості поведінки бактерій під час сублімаційного сушіння за використання різних захисних середовищ. Запропоновано таку умовну класифікацію штамів за цим показником:

- культури, які втрачають за сушіння менше 10\% клітин, нагромаджених за час ферментування, мають високий РЗЖ і відповідно є стійкими;

- культури, кількість загиблих клітин у яких не перевищує 20\%, мають середній рівень РЗЖ і характеризуються як середньо стійкі;

- культури, у яких після сушіння чисельність клітин зменшується більше ніж на 20\%, мають низький РЗЖ і є не стійкими.

Здатність до виживання за сублімаційного сушіння мезофільних лактобактерій представлено у таблиці 1. Вихідна концентрація мезофільних молочнокислих лактококів до ліофілізації становила $\lg 9,4$ та $\lg$ 9,7 КУО/ $\mathrm{cm}^{3}$ для L. lactis SB 44 та L. lactis SB 16 від- повідно. Результати засвідчують, що більшу захисну дію проявляло сахарозо-желатозне середовище, до складу якого входили желатин та сахароза. Кращою життєздатною властивістю за цих умов характеризувався штам L. lactis SB 16, кількість загиблих за сушіння клітин якого становила 9,2\%. При використанні білково-вуглеводневого захисного середовища кількість загиблих за сушіння клітин для цього штаму становила $16,1 \%$.

Ще одним критерієм відбору монокультур до складу заквашувальних композицій є висока молокозсідальна активність (МЗА), яку оцінювали за тривалістю утворення згустку. Вищою МЗА характеризувався штам SB 16 при використанні сахарозожелатозного захисного середовище, тривалість сквашування складала 8 год. Рівень граничної кислотності у молоці становив $120^{\circ} \mathrm{T}$ (4,67 од. pН). Це дає підстави очікувати, що залучення його до складу бактеріальних препаратів розширить спектр функціональної активності продукту та забезпечить стабільність перебігу технологічних процесів. Штам SB 44 характеризувався низькою МЗА при використанні двох захисних середовищ. При використанні цього штаму активна кислотність молока коливалася в межах 4,754,82 од. $\mathrm{pH}$.

Рівень збереження життєздатності мезофільних МКБ

Таблиияя 1

\begin{tabular}{|c|c|c|c|c|c|}
\hline \multirow{3}{*}{$\begin{array}{c}\text { № } \\
\Pi / \Pi\end{array}$} & \multirow{3}{*}{ Показники } & \multicolumn{2}{|c|}{ L. lactis SB 16} & \multicolumn{2}{|c|}{ L. lactis SB 44} \\
\hline & & \multicolumn{4}{|c|}{ Захисне середовище } \\
\hline & & 1 & 2 & 1 & 2 \\
\hline 1. & 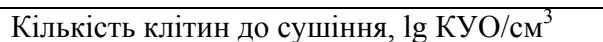 & \multicolumn{2}{|c|}{9,7} & \multicolumn{2}{|c|}{9,4} \\
\hline 2. & Кількість клітин після сушіння, $\lg$ КУО/ $\mathrm{cm}^{3}$ & 8,3 & 8,9 & 7,6 & 8,1 \\
\hline 3. & Кількість загиблих за сушіння клітин, \% & 16,1 & 9,2 & 21,4 & 15,5 \\
\hline 4. & РЗЖ & Середній & Високий & Низький & Середній \\
\hline 5. & Титрована кислотність молока, ${ }^{\circ} \mathrm{T}$ & 115 & 120 & 116 & 118 \\
\hline 6. & Активна кислотність молока, од рН & 4,84 & 4,67 & 4,82 & 4,75 \\
\hline 7. & МЗА, год. & 12 & 8 & 16 & 10 \\
\hline
\end{tabular}

Здатність до виживання при сублімаційному сушінні термофільних лактобактерій представлено у таблиці 2. За нашими результатами, штами L. plantarum показали після сушіння нижчий рівень збереження життєздатності, ніж мезофільні лактококи. Слід зазначити, що серед досліджуваних штамів L. plantarum найкращою життєздатною властивістю характеризувався штам SB 17 при використанні сахарозо-желатозного середовища, кількість загиблих за сушіння клітин становила 9,9\%, а відповідно характе- ризувався як стійкий. Інші штами, на жаль, є менш перспективними для конструювання бактеріальних композицій при виробництві кисломолочних продуктів.

Максимальний показник кислотоутворення після інкубації за температури $37^{\circ} \mathrm{C}$ протягом 24 год. $\left(160^{\circ} \mathrm{T}\right)$ встанговлений для бактерій штаму SB 17, для ліофілізації якого використано сахарозо-желатозне захисне середовище.

Рівень збереження життєздатності термофільних МКБ

Табличя 2

\begin{tabular}{|c|c|c|c|c|c|c|c|}
\hline \multirow{3}{*}{$\begin{array}{c}\text { № } \\
\Pi / \Pi\end{array}$} & \multirow{3}{*}{ Показники } & L. plantc & um SB 5 & L. plant & im SB 7 & L. plant & $n \mathrm{SB} 17$ \\
\hline & & \multicolumn{6}{|c|}{ Захисне середовище } \\
\hline & & 1 & 2 & 1 & 2 & 1 & 2 \\
\hline 1. & 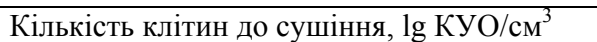 & \multicolumn{2}{|c|}{8,7} & \multicolumn{2}{|c|}{8,5} & \multicolumn{2}{|c|}{8,9} \\
\hline 2. & 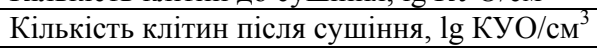 & 6,5 & 7,7 & 6,3 & 6,5 & 7,2 & 8,1 \\
\hline 3. & Кількість загиблих за сушіння клітин, \% & 25,3 & 11,5 & 25,6 & 23,5 & 19,1 & 9,9 \\
\hline 4. & ( & $\begin{array}{c}\text { Низь- } \\
\text { кий }\end{array}$ & $\begin{array}{c}\text { Серед- } \\
\text { ній }\end{array}$ & $\begin{array}{c}\text { Низь- } \\
\text { кий }\end{array}$ & $\begin{array}{c}\text { Низь- } \\
\text { кий }\end{array}$ & $\begin{array}{c}\text { Серед- } \\
\text { ній }\end{array}$ & $\begin{array}{c}\text { Висо- } \\
\text { кий }\end{array}$ \\
\hline 5. & Титрована кислотність молока, ${ }^{\circ} \mathrm{T}$ & 161 & 159 & 157 & 161 & 158 & 160 \\
\hline 6. & Активна кислотність молока, од рН & 4,2 & 4,25 & 4,32 & 4,18 & 4,3 & 4,22 \\
\hline 7. & МЗА, год. & 28 & 27 & 25 & 27 & 26 & 24 \\
\hline
\end{tabular}


Результати досліджень впливу складу захисного середовища на виживання термофільних лактобактерій у процесі ліофілізації дозволили підтвердити дані про те, що у сахарозо-желатозному середовищі моноцукри і полісахариди, а також білки і продукти їхнього гідролізу є основними компонентами, оскільки вони виконують функцію стабілізатора зв'язаної води у клітинах (Belov et al., 1993).

Оскільки за отриманими даними кращим для сушіння монокультур $є$ сахарозо-желатозне захисне середовище, проведено порівняльне дослідження рівня збереження життєздатності різних видів МКБ за різних умов зберігання. Динаміку виживання монокультур МКБ досліджували у двох режимах: 1) витримування упродовж 30 діб у знежиреному молоці за температури $\left.(+6)^{\circ} \mathrm{C} ; 2\right)$ у ліофілізованому стані протягом 6 міс. за температури $(-18){ }^{\circ} \mathrm{C}$. Динаміку відмирання клітин за цих умов представлено на рисунках 1 i 2 .

Дані, наведені на рисунку 1, свідчать, що витримування монокультур за режиму 1 впливає на їх життєздатність. Досліджені культури, особливо термофільні МКБ, поступово починають втрачати нагромаджену кількість клітин вже через 5 діб зберігання.

Усі штами молочнокислих бактерій, за винятком штаму L. lactis SB 16 за температури зберігання $(+6){ }^{\circ} \mathrm{C}$ через місяць втрачають від 4 до $15 \%$ життездатних клітин. Серед термофільних молочнокислих бактерій стійким до відмирання виявився штам SB 17, який за 30 діб зберігання втратив 3,8\% клітин.

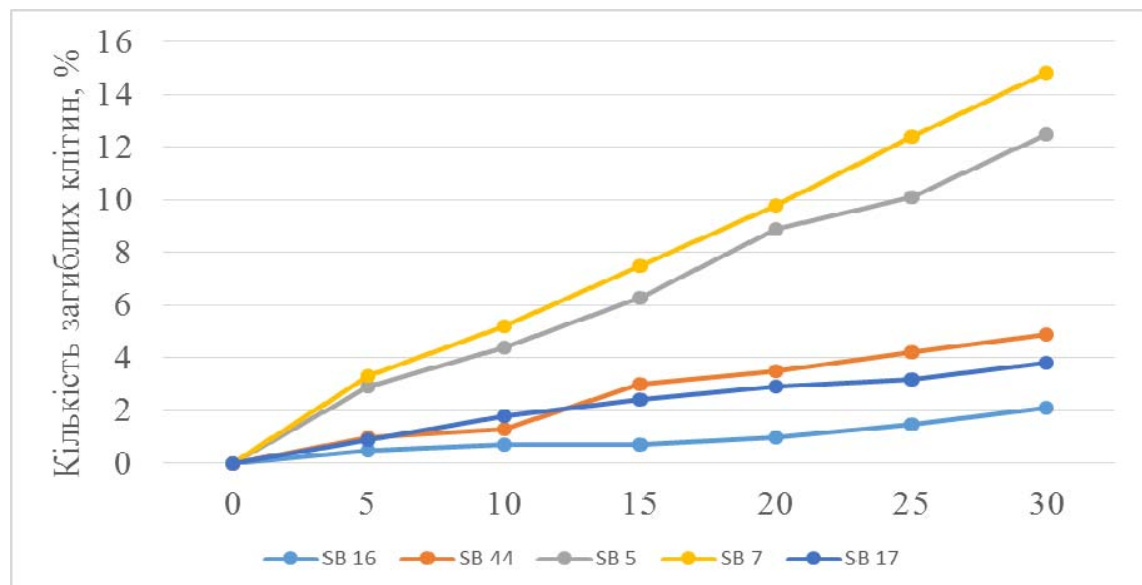

Рис. 1. Динаміка втрачання життєздатності МКБ під час зберігання у знежиреному молоці за температури (+6) ${ }^{\circ} \mathrm{C}$

Дані, наведені на рисинку 2, свідчать, що у ліофілізованому стані культури, особливо штами L. plantarum SB 5 та L. plantarum SB 7 поступово починають втрачати нагромаджену кількість клітин через 1 місяць. На кінець досліду, кількість загиблих клітин в них становить 25-26\%. Кращою життєздатною властивістю за цих умов характеризувався штам L. lactis SB 16, кількість загиблих клітин протягом зберігання за температури $(-18){ }^{\circ} \mathrm{C}$ становила $21 \%$. Серед термофільних молочнокислих стрептококів найстійкішим виявився штам L. plantarum SB 17 (кількість загиблих клітин протягом зберігання 22,7\%).

Одержані у цих дослідах результати дозволяють зробити висновок, що термін зберігання штамів $L$. lactis та L. plantarum у сухій культурі становить 6 міс.

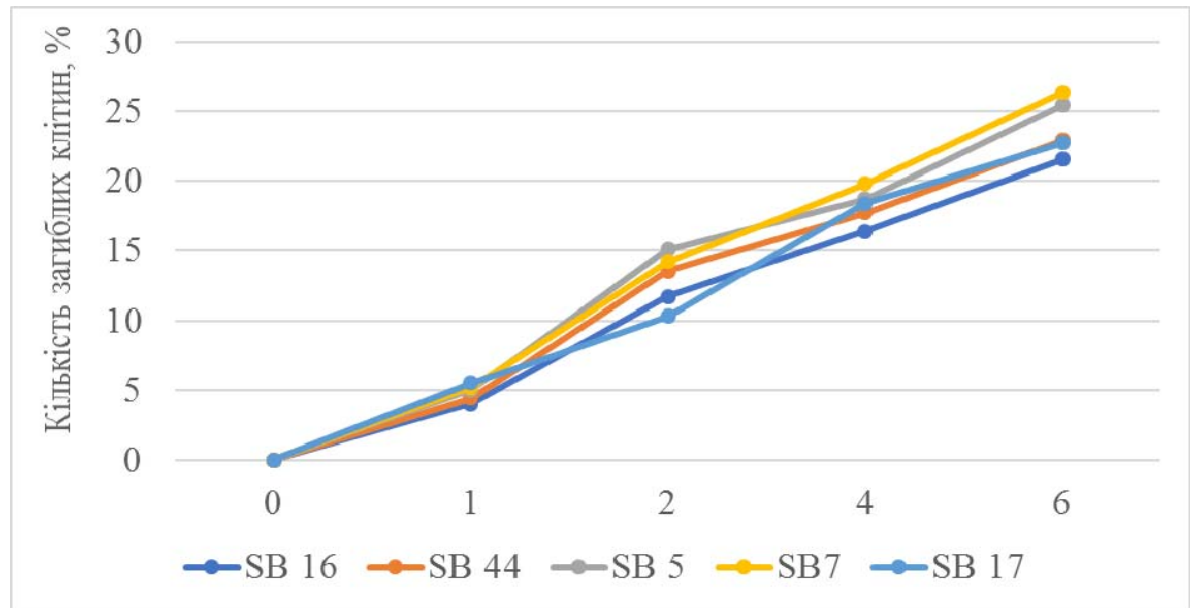

Рис. 2. Динаміка втрачання життездатності МКБ під час зберігання у ліофілізованому стані за температури $(-18){ }^{\circ} \mathrm{C}$ 


\section{Висновки}

1. Встановлено, що за своїми кріопротекторними властивостями кращим для сушіння досліджених монокультур $є$ сахарозо-желатозне середовище, яке забезпечує високий РЗЖ, особливо для L. lactis SB 16 (кількість загиблих під час сушіння клітин становила 9,2\%) та L. plantarum SB 17 (кількість загиблих під час сушіння клітин становила 9,9\%).

2. Встановлено, що усі штами молочнокислих бактерій, за винятком штаму L. lactis SB 16 протягом зберігання у знежиреному молоці за температури (+6) ${ }^{\circ} \mathrm{C}$ через місяць втрачають від 4 до $15 \%$ життездатних клітин. Термін зберігання штамів L. lactis та L. plantarum у сухій культурі становить 6 міс.

Перспективи подальших досліджень. В подальшому ліофілізовані молочнокислі культури L. lactis та L. plantarum будуть використанні для створення бактеріального препарату для виробництва бринзи.

Робота виконана в рамках наукового проекту «Біотехнологія створення вітчизняних бактеріальних препаратів для молочної промисловості» (номер держреєстрації № 0116U208537).

\section{Бібліографічні посилання}

Slyvka, I.M., Cisaryk, O.J. (2016). Biotehnologija stvorennja vitchyznjanyh bakterial'nyh preparativ dlja molochnoi' promyslovosti Ukrai'ny. Naukovyj visnyk LNUVM ta BT imeni S.Z. Gzhyc'kogo. 12, 2(68), 103-110 (in Ukrainian).

Basjul, O.V., Jamborko, G.V., Ivanycja, V.O. (2014). Vplyv skladu zahysnyh seredovyshh na zberezhennja zhyttjezdatnosti ta biotehnologichnyh vlastyvostej liofilizovanyh bakterij LACTOBACILLUS
PLANTARUM ONU315. Visnyk ONU. 19, 1(34), 915 (in Ukrainian).

Golovach, T.M., Groma, L.I. (2004). Laktobacyly: zamorozhuvannja pry nyz'kyh ta ul'tranyz'kyh temperaturah. Metody oderzhannja chystyh kul'tur mikroorganizmiv ta i'h dovgostrokovogo zberigannja v kolekcijah. Kyi'v: Tov. «Znannja Ukrai'ny», 39-44 (in Ukrainian).

Belov, A.N., Belova, L.P., Krivorotova, T.L., Guseva, N.M. (1993). Vlijanie sostava zashhitnyh sred pri sublimacii i hranenii koncentratov termofil'nyh molochnokislyh bakterij. Molochnaja promyshlennost'. 1, 25-26 (in Ukrainian).

Jeres'ko, G.O., Nasyrova, G.F., Romanchuk, I.O., Kigel', N.F. (2001). Sposib oderzhannja suhogo bakterial'nogo preparatu dlja fermentovanyh molochnyh produktiv. Pat. №33321, Ukrai'na. Opubl. 15.02.2001, Bjul. №1 (in Ukrainian).

Romeo, Y., Bouvier, J., Gutierres, C. (2001). Osmotic stress responce of lactic acid bacteria Lactococcus lactis and Lactobacillus plantarum. Lait. 81(1), 49-55.

Blankov, B.I., Klebanov, D.L. (1987). Primenenie liofilizacii v mikrobiologii. M.: Medgiz (in Russian).

Cisaryk, O.J., Slyvka, I.M., Bocer, T. (2014). Zastosuvannja metodu RAPD-PCR dlja identyfikacii' molochnokyslyh bakterij. Zhurnal «Biologija tvaryn». 16(4), 143-149 (in Ukrainian).

Cisaryk, O.J., Slyvka, I.M. (2015). Identyfikacija molochnokyslyh bakterij iz zastosuvannjam kompleksu molekuljarno-genetychnyh metodiv. Naukovyj visnyk LNUVMBT imeni S.Z. Gzhyc'kogo. 17, 1(61), 213-222 (in Ukrainian).

Sbornik instrukcij po selekcii molochnokislyh bakterij i bifidobakterij i podboru zakvasok dlja kislomolochnih produktov (1985). M., 101 (in Russian).

Стаття надійшла до редакиії 15.03.2017 